\title{
The Effect of Situational Leadership Behavior Organizational Culture and Human Resources Management Strategy on Education and Training Institution Productivity (Survey on Educational and Vocational Training Institutions in West Java Province)
}

\author{
I. Iskandar' \\ ${ }^{1} B S I$, Sunan Gunung Djati, State Islamic University Bandung \\ E-Mail: iskandar@gmail.com
}

\begin{abstract}
The aim of this research is to analyze: situational leadership behavior, organizational culture and productivity of vocational training institutes in west Java Province. The correlation between situational leadership behavior and organizational culture at vocational training institutes, the effect of situational leadership behavior and organizational culture toward productivity of vocational training institutes in west Java Province. This research uses organizational behavior and human resources management approach. The type of the research is descriptive and verificative, while the method used both descriptive and explanatory survey. Investigation type is casualty and time horizon in cross sectional. The sample size used is proportionate sampling by taking sample 115 vocational training institute of spread over 19 locations totally, all its population counted 719 vocational training institutes in west Java Province. The data analyzed by descriptive analytic and path analysis. The result of research shows, 1) situational leadership behavior and organizational culture in generalities, rather high score and the productivity at vocational training institutes to society, cooperation with company or industry in training program development, and placement of training graduate assessed by rather low, 2) there is correlation which significant between situational leadership behavior and organizational at vocational training institutes in west Java Province, 3) situational leadership behavior, organizational culture has significant effect simultaneously and partially productivity of vocational training institutes in west Java Province.
\end{abstract}

Keywords: Leadership, organizational culture, human resources management strategy and productivity.

\section{A. INTRODUCTION}

Education service industry and vocational training have good prospect, for the society need on relating to education and vocational not only for the work force looking for a job, but also for those who have got a job and starting their own business. They want to have and increase knowledge, skill and more productive work. This prospect can be handled and managed by vocational training institutes and education as good chance to give better service education and vocational training, as the society expects especially for the new work force. The institutes are expected to teach to increase knowledge, skill and work character, either for work force or those who have got a job to increase the competence based on the demand of need of work market. The level of success of vocational educational and training institute determined by operation quality and the service of education and training, quality of equipment, facility and the quality of human resources. By having better training and education operation and its professional human resources, the institute will be more needed by the society. There are many factors influencing level of effectivity of the institute facility such as a: the growth rate of work force, economic social, the mind of work market or industry, the environment and trust of society. According to (Schroeder 2000: 80), service 
operation and service delivery system having high-contact service, need support of physical environment and contact personnel to meet the certain purpose of company as vocational education and training institute operated. It is in accordance with (Lovelock 2002:53), that interaction intensity in operation and service delivery can be operated in high-contact service, service delivery that needs high interaction among customers, workers, equipment, and other source of facilities.

Physical support, as the equipment, location and contact personnel in operation and delivery service, need situational leadership, organizational culture and the implementation of human resources management strategy. The effective strategy of implementation will produce responsible worker with high motivation and ability (knowledge, skill) and his or her behavior in influencing productivity, quality and institutional profitability (Noe et al. 2000:53, Mello et al. 2002:10, Kreitner et al. 2003:67). Situational leadership behavior showed by a leader in combination of task behavior and communication behavior and level of the accountability of workers determining right leadership behavior. (Blanchard et al., 1993:192). Organizational culture function in operation and delivery service managed by the effective leadership behavior and the implementation of human resources management strategy can increase institution productivity and the satisfaction of worker (Kreitner et al. 2006:86). The function of organizational culture is a controller and maker of mechanism, guiding of productive work behavior (Robbins 1998:283). Organizational culture forces growth having influence on institution productivity and work satisfaction (Robins 1998:308).

Human resources management strategy implementation with its operational function (recruitment, selection, training, scoring, work scoring, compensation and communication of manpowership) increase institution productivity and contribute positively institution strategy implementation, because they can use technology, produce something or high quality service and find product market or service they have (Mello 2002:237). According to Mello investigation (2002:107), the effective implementation of human resources management strategy can increase performance and productivity, customers' and employees' satisfaction and increase security value for shareholder value. The study of Noe et al. (2000:53), showed that implementation of human resources management strategy has determined contribution to synergy enhancing, productivity, quality and profitability of institution or company. Productivity denotes measurement of quality and quantity or work done by a manpower considering resources fund used to operate (Jackson et al. 2000:84). Productivity is the measurement of synergy including effectivity and efficiency. Effectivity means achievement, the efficiency is comparation between effective income/outcomes needed to reach it (Robins 2001:22). The productive manpower will decrease cost operation and assure of customer satisfaction, when it is supported by leadership behavior, culture, system and technology (Schroeder, 2000:84). The increasing of productivity of vocational training and education is influenced by situational leadership behavior, organizational culture implementation and implementation of human resources management strategy. The increasing of productivity, quality and profitability of institution or company, is superiority in getting competitive advantage. Situational leadership behavior and organizational culture have positive relation that can accommodate human ability in implementing human resources management strategy having positive influence on institution productivity (Blancard et al., 1993, Kreitner et al., 2000). Organizational culture is a perception organization member as a system has positive influence on institution productivity (Robins 1998, Kreitner et al. 2003). The construction of organizational culture motivate employees to do their tasks and interact will others, increase productivity, the implementation of human resources management strategy create contributive and influencing human resources positively on institution productivity (Noe et al. 2000, Mello 2000). Recruitment and selection of right candidate of worker, institution gets highly competitive manpower to work productively. The implementation of compensation in finance or non-finance fairly, increasing work 
motivation and productivity. Cooperation in harmony can increase productivity of institution (Mello 2000, Noe et al. 2000, Dessler 2001, Jackson et al 3002).

The phenomenon at present is the level of facility utility of vocational training and education with society is still low. As tie fact that most of education and training facility, such as: practice and theory room, equipment and human resources are not effectively used training and education. Theory and practice room design are in disorder. Physical environment maintenance such as: building and its environment are most not in operation. Park and supporting means are not in good order. Most of vocational education and training are not only prepared to increase its productivity, but also unprepared to compete in business. This phenomenon is assumed because lack of professionality of manager in running education and training, there is not right leadership behavior, low level of culture implementation of organization and implementation of human resources management strategy. Leadership behavior is not implemented in in task behavior; behavior relationship is not according to level of professionalism of workers. Instruction, motivation, direction and guidance and movement of leader is not according to professionalism of workers. In such a situation, they need effective and flexible leadership behavior to adapt between workers. The implementation of organizational culture is not effective, it is seen from the lack of manpower's awareness to work together to get goal, less creative, innovative and normative. The implementation of human resources management strategy covering recruitment, selection, training, work scoring, compensation and manpowership relation have not been supported by leadership behavior and implementation of effective organizational culture.

Relating to recruitment, selection and training, institution has not been successful to have competent manpower appropriate to the position they have. Vocational training has not been appropriate to the analysis of training need. Synergy scoring has been rarely carried out, compensation system is not appropriate and relation of manpowership has not been in harmony. Behavior of staff and instructure and lecturer must be increased, for lateness often happens in education operation and training. Lecturer's compensation is still low, either in skill or teaching method. The strong leadership behavior is needed to solve the change happening in external environment, such as business competition, government policy, technology progress, society wants and social economic change. The change influences institution strategy formula and the implementation of human resources management strategy (Mello 2002: 107). The implementation of human resources management strategy needs leadership behavior and effective organizational culture to produce the accountable man power in carrying out the activities to get synergy, productivity, quality and profitability of company (Noe et al. 2000:53). This strategy needs human resources commitment formed in organizational culture, so that they will have positive contribution. Human resources is demanded to have role in determining performance drivers and as performance enablers of institution to increase quality and productivity to win the competition.

\section{B. METHODOLOGY}

This research uses organizational behavior and human resources management approach. The type of the research is descriptive and verificative, while the method used both descriptive and explanatory survey. Investigation type is casualty and time horizon in cross sectional. The sample size used is proportionate sampling by taking sample 115 vocational training institute of spread over 19 locations totally, all its population counted 719 vocational training institutes in west Java Province. The data analyzed by descriptive analytic and path analysis 


\section{RESULT AND DISCUSSION}

\section{Situational Leadership Behavior}

Organizational Culture and Implementation of Human Resources Management Strategy and Productivity of Vocational education and Training.

Situational leadership behavior is the right combination of task behavior, relation behavior and level of worker professionalism. The result of research shows that most of Situational leadership behavior by releasing combination of task behavior, relation behavior situation of level of worker professionalism is still low to medium, and high. It is appreciate to (Blanchard et al. 1997: 84), that Situational leadership behavior aimed proportional task behavior between task behaviors, the behavior of level relation of worker professionalism. Task behavior, to determine purpose, guidance instruction, direction and controlling. Relation behavior: motivating, communication, consultation and cooperation. The level of worker professionalize, is ability of worker to do the task.

The result of research shows that the level of leader's ability in implementing constructive organizational culture is high. And passive-defensive organizational culture is aggressivedefensive. It means, most respondent give high score on the level of leader's ability in implementing constructive organizational culture on vocational education and training of this research appropriate to Kreitner et al. (2003:86), that implementing organizational culture is an assumption, it is accepted implicitly by the manpower's that determines as manpower experience, think and react on various environment.

The result of research shows that if the level of leader's ability in implementing human resources management strategy including recruitment, selection, training, compensation and manpowership relation. This result is appropriate to Schroeder (2000:60), that vocational education and training as training service supplier is high contact service, so human resources is a man in part of company operation to meet requirements for customers.

\section{The Productivity Measuring of Vocational Education and Training}

The total Productivity Measuring Pengukuran produktivitas of vocational education and training carried out by considering output total or profit in earning before taxes resulted by vocational training and input total (Rusli Syarif). Earning before taxes are profit from education donation of participants the component of operational fund is the outcome of institution, it consists of: expense of material in training, fee of staff, expense of capital and scoring administration. The productivity of institution is increasing. This result is appropriate to level of efficiency of education and training and capacity, which is used. The result of research shows that it is necessary to increase cooperation between institution leader and industry, in developing training and education program, apprenticeship for university students or participants and for graduate placement.

\section{Situational Leadership Behavior correlation}

The research investigates the correlation between Situational leadership behavior and organizational culture. It means if there is a change of Situational leadership behavior, it will be impact for organizational culture. It shows there is significant correlation between Situational leadership behavior and organizational culture on the institution. But the situational leadership behavior is necessary and constructive organizational culture and vice versa. 
This result is appropriate to Mello (3003:107), that leadership behavior and culture in the company is important factor in increasing productivity totally.

\section{The Influence of Situational Leadership Behavior and Organizational Culture on implementation of Human Resources Management Strategy}

It means there is influence of situational leadership behavior and organizational culture on implementing human resources management strategy toward institution. Partial test, situational leadership behavior and organizational culture have significant influence on implementing human resources management strategy, as showed at the following table.

Table 1.0 Analysis Path statistic and partial influence of Situational Leadership Behavior and Organizational Culture on the Implementation of Human Resources: Management Strategy

\begin{tabular}{|c|c|c|c|c|c|}
\hline $\begin{array}{l}\text { Structural } \\
\text { Parameter }\end{array}$ & Coefficient & T counted & T Table & Decision & Influence \\
\hline$P \times 3 \times 1$ & 0,23 & 2,14 & 1,98 & Refusing Ho & Significant \\
\hline$P \times 3 \times 2$ & 0,25 & 2.37 & 1,98 & Refusing Ho & Significant \\
\hline
\end{tabular}

Note: $\mathrm{X} 1=$ Situational leadership behavior

$\mathrm{X} 2=$ Organizational Culture

$\mathrm{X} 3=$ Implementation of human resources management strategy

Significant level test $(\alpha) 5$ percent is found partial leadership behavior on implementing human resources management strategy is 23 percent; the influence of organizational cultural is 25 percent. This research investigates, situational leadership behavior and organizational culture is significant simultinuously and partially on implementing human resources management strategy. The implementation human resources management strategy supported by situational leadership behavior and organizational culture, so the institution can reach the goal. Situational leadership behavior in non-government vocational education and training showed by leader in combination with behavior relating to task and human resources and its worker professionalism (Blanchard et al. 1993:192).

Organizational culture determines manpower in institution to the their work in cooperation an normative. Organizational culture is the assumption, accepted by all employees in institution and determines personally, think and cooperate to increase institution productivity. This result is appropriate to Kreitner et al. (2003:89), there are four general manifestation of organizational culture, and all members owned, the same word, work together in an organization to increase institution productivity.

\section{The Influence of Implementation of Human Resources Management Strategy and Productivity of Vocational education and Training.}

The result of research finds that the implementation of human resources mangement strategy influences directly on institution productivity. There are still many variables that can increase institution productivity like physical support. The direct and indirect influence of implementing strategy on institution productivity. The result of statistic test, shows that human resources management strategy significantly influential on institution productivity. 


\section{The Influence of Situational Leadership behavior, Organizational Cultured the Implementation of Human Resources Management Strategy on Vocational Education and Training Productivity.}

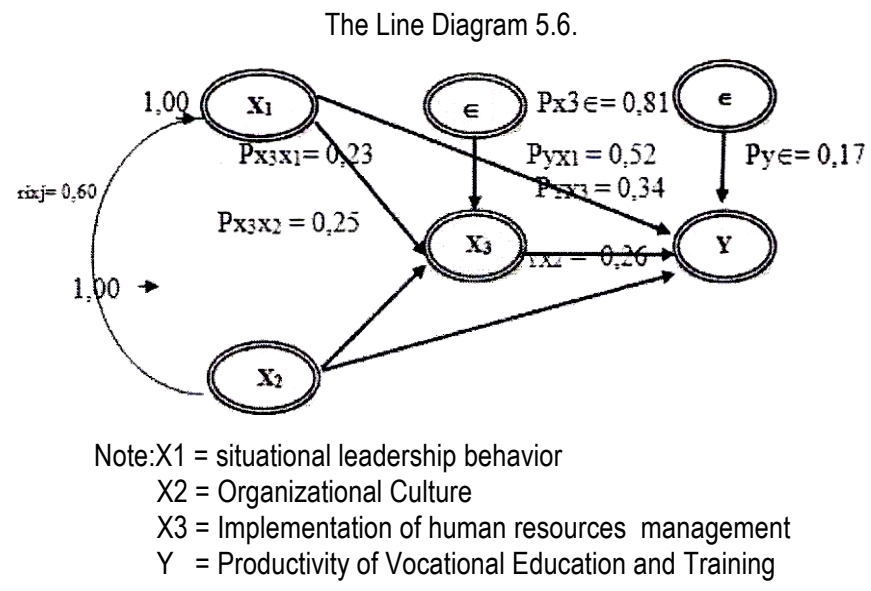

The result of Test Counting of determination coefficient, finds that situational leadership behavior, Organizational Culture and Productivity of Vocational Education and Training either simultinuously or partially bas significant influence on productivity of test institution significantly or simultinuously.

Statistic Test Result of partial of Situational Leadership Behavior, Organizational Culture and the Implementation of Strategy on Productivity.

\begin{tabular}{|c|c|c|c|c|c|}
\hline $\begin{array}{l}\text { Structural } \\
\text { Parameter }\end{array}$ & $\begin{array}{c}\text { Line } \\
\text { Coefficient }\end{array}$ & T Counting & T Table & Decision & Influence \\
\hline$P \times 3 \times 1$ & 0,52 & 10,45 & 1,98 & Refusing $\mathrm{Ho}$ & Significant \\
\hline PX3X2 & 0,26 & 5,26 & 1,98 & Refusing $\mathrm{Ho}$ & Significant \\
\hline Pyx3 & 0,34 & 7,78 & 1,98 & Refusing $\mathrm{Ho}$ & Significant \\
\hline
\end{tabular}

The direct and indirect influence of situational leadership behavior, Organizational Culture and Implementation of human resources management strategy institution productivity: (1). There is direct influence of situational leadership behavior determines institution productivity and through Organizational Culture, Implementation of human resources management strategy. Total influence of situational leadership behavior determinism situation productivity; (2). There is direct influence of Organizational Culture determining institution productivity change through institutional leadership, by Implementation of human resources management strategy; Total influence of organizational culture determines institution productivity change (3). There is direct influence of Implementation of human resources management strategy institution productivity change, through situational leadership behavior with Organizational Culture. Total influence of Implementation of human resources management strategy determines institution productivity change. Based on the analysis above can be stated that situational leadership influences directly. The result of research is appropriate to Mello (2002:237), The implementation of human resources management strategy gives contribution on corporate strategy, they can use technology and produce something and service in good quality.

Organizational Culture and Implementation of human resources management strategy has significant influence on productivity increasing of vocational education and training. Partially situational leadership behavior determines institution productivity change more than Organizational 
Culture and Implementation of human resources management strategy.

\section{CONCLUSION}

Based on the result of research and discussion:

1. Situational leadership behavior and organizational cultures not excellent in general. Implementation of human resources management strategy and productivity on institution is medium in general. Except, contribution of training institution to society, such as special bursary work, scholarship, cooperation with industry at the framework of placement graduate, apprentice program and program development is considered as low.

2. Situational leadership behavior correlates significantly to constructive organizational culture for institution. It means, situational leadership behavior, including dimension of telling, selling, participating and delegating with implementation of organizational culture related and support in Implementation of human resources management strategy and productivity increasing.

3. Situational leadership behavior and organizational culture in simultanuous or partial has significant influence on Implementation of human resources management strategy. Perilaku kepemimpinan situasional can influence, change and generate the action of manpower Implementation of human resources management strategy, so that they can work more productive to increase productivity.

4. Constructive organizational culture motivates a group of manpower in completing task to reach goal together, normative, innovative and creative and support implementation of human resources management strategy and productivity increasing.

5. Pelaksanaan strategi manajemen sumber daya manusia has significant influence on productivity increasing of institution in competent human resources that can implement technology in operation and delivery service of training produce qualified graduate.

6. Situational leadership behavior, constructive organizational culture and Implementation of human resources management strategy including recruitment, selection, training, synergy scoring, compensation and manpowership relation either in simultinuous or partial has significant influence on productivity increasing of vocational education and training institution. 


\section{References}

Becker, Brian E., Mark A. Huselid, Dave Ulrich. (2001). HR Scorecard Lingking People, Strategy and Performance. Harvard Business School Press. Boston: Massachusetts.

Blanchard, K and P. Hersey. (1993). Management of Organizational Behavior. Utilizing Human Resources, 6th edition, Prentice Hall Inc.. Engelwood Clifts: New Jersey.

Cassio, Wayne F. (1995). Managing Human Resources: Quality of Life, and Profit. Third Edition, New York: Mc Graw-Hill, Inc.

Chase, Richard B., Nicholas .J., Aquilaro and Robert F. Jacobs. (1998). Production and Operation Mangement: Manufacturing and Service. Boston: Irwin Mc.Graw-Hill.

Cravens, David W. (1996). Strategic Marketing, MJ. Neesley School of Business. Texas: Christian University.

Cushway, Barry. (2002). Human Resources Management. AMED (The Association for Management Education and Development). Jakarta: P.T. Elex Media Komputindo Gramedia.

Harun, Cut Zahri. (2005). Peningkatan Kualitas Sumber Daya anusia Melalui Pendidikan Merupakan Kunci Keberhasilan Suatu Lembaga Di Era Globalisasi dan Otonomi Daerah. Jakarta : Departemen Pendididkan Nasional.

Dalton, D., WD., Todor. (1998). Functional Turnover and Absenteeism: An Empirical Assessment. Journal of Applied Psychology and Industry, page 62.

Dessler, Gary. (2000). Human Resources Management. Eight Editions, California: Prentice Hall International Inc.

Devis, Walter D. (2000). The Development of Self-efficacy during Aviation Training. Journal of Organizational Behavior. U.S.A: Purdue University, West Lavayette.

Fulmer, Robert M. (2001). Johnson \& Johnson: Frameworks for Leadership. Journal of Organizational Dynamics, 20(3).

Gibson, James L, John M., Ivancevich, James H., Donnely Jr. (1997). Organisasi. Edisi Ke Delapan. Jakarta: Binarupa Aksara. 